\title{
METASOMATISM AT CONTACTS OF ACID ROCKS WITH ANORTHOSITE AND AMPHIBOLITE IN THE FISKENÆSSET REGION
}

\author{
Giorgio Rivalenti
}

\begin{abstract}
Introduction
During the geological mapping in the Fiskenæsset region the origin of the different gneiss types has been much debated, and it has been suggested that some of the gneisses may represent metasomatically altered anorthositic and amphibolitic rocks. F. Kalsbeek suggested that to test this hypothesis a study should be made of possible mineralogical and chemical changes at boundaries between anorthositegneiss and amphibolite-gneiss. The first results of such an investigation are reported here.

In the area mapped by the writer, anorthosites and amphibolites occur both as continuous layers, concordant with the gneiss foliation, and as lenses and boudins embedded in gneiss or in pegmatitic material. The continuous layers are also often cut by pegmatites or granitoid rocks. The amphibolites show both gradational and sharp contacts with gneisses and pegmatites. The anorthositic rocks usually appear to have sharp contacts with the gneisses, but since both rock types are leucocratic and rather fine grained it is often difficult to study the contact relationships in the field.
\end{abstract}

\section{Sampling}

Samples for this study were collected at three localities which are briefly described below.

\section{Locality 1}

The outcrop consists of an antiformally folded sequence of granitic gneisses which are overlain by meta-anorthosite and underlain by strongly pegmatized dark amphibolite, which is in turn underlain by a gabbro-anorthosite zone. The contact between the gneisses and the anorthosites is usually sharp and often marked by a thin $(1-3 \mathrm{~cm})$ pegmatite. Small anorthosite inclusions are found in the gneiss 
near the contact. The anorthosite is slightly banded and contains rare quartzofeldspathic veins. The amphibolites are banded and contain thick (up to $10 \mathrm{~m}$ ), concordant or slightly discordant, sheets of a medium-grained, slightly gneissic pegmatite. The contact between amphibolites and pegmatites is sharp and is marked by an enrichment in biotite. Amphibolite inclusions, apparently untransformed, are present in the pegmatites. Wedge-shaped amphibolite inclusions may thin out into pegmatite or gneiss and continue within them as biotite-rich schlieren.

\section{Locality 2}

The outcrop is formed of hornblende-biotite gneiss, rich in amphibolite inclusions of various sizes. The rocks are folded on ENE axes. The passage from the amphibolite inclusions to the gneiss is not knife sharp but takes place within a few centimetres.

\section{Locality 3}

A leucogabbro horizon, locally penetrated and disrupted by pegmatitic and microgranitic material, thus assuming an agmatitic structure. The contacts between the leucosomes and the leucogabbro are sharp.

\section{Petrographical and chemical effects at the contact zones}

Thin sections of the samples have been point-counted (approx. 3000 points per thin section) and the composition of the plagioclase has been determined with the help of the universal stage using the determination curves of Emmons (1959). Major and trace elements, excluding $\mathrm{H}_{2} \mathrm{O}$ and $\mathrm{Na}_{2} \mathrm{O}$, have been determined by $\mathrm{X}$-ray fluorescence, according to the method of Franini \& Leoni (in press); $\mathrm{Na}_{2} \mathrm{O}$ has been determined by atomic absorption. The results of the investigations are reported in table 7 and can be summarized as follows:

(1) Near the contact with the gneisses the plagioclase in the anorthositic rocks becomes more sodic. In the unaltered anorthosites and leucogabbros the An contents are around $90 \%$ (Windley, 1969); in the contact samples in localities 1 and 3 they decrease to $56 \%$ and $53 \%$ respectively. The same happens in the amphibolites of locality 1 . The An content of the gneiss plagioclase increases towards the anorthositic rocks in locality 1 , and at the contacts between anorthosite or leucogabbro-gneiss and amphibolite-gneiss the composition of the plagioclase in the two rock types becomes more or less the same.

(2) Near the contact, the quartz content in the anorthositic rocks increases at locality 3 , but not at locality 1 , and the quartz content in the bordering gneisses 
Table 7. Analyses of contacts of acid rocks with anorthosite and amphibolite

\begin{tabular}{|c|c|c|c|c|c|c|c|c|c|c|c|c|c|c|}
\hline \multirow[b]{4}{*}{$\mathrm{SiO}_{2} \%$} & \multirow{4}{*}{$\begin{array}{c}\text { Loc, } 1 A \\
85868 \\
\text { Anorth. } \\
10 \mathrm{~m} \\
52.45\end{array}$} & \multicolumn{8}{|c|}{ Boundary of anorthosite and gneiss } & \multicolumn{5}{|c|}{$\begin{array}{c}\text { Loc. } 1 B \text { Boundary of amphibolite and } \\
\text { pegmatite }\end{array}$} \\
\hline & & & \multirow{2}{*}{\multicolumn{2}{|c|}{$\begin{array}{l}85871 \text { D } 85872 \\
\text { Anorth. Pegm. } \\
\text { contact contact }\end{array}$}} & \multirow{2}{*}{$\begin{array}{c}85871 B \\
\text { Gneiss } \\
\text { contact }\end{array}$} & \multirow{2}{*}{$\begin{array}{r}85871 \mathrm{~A} \\
\text { Gneiss } \\
15 \mathrm{~cm}\end{array}$} & \multirow{2}{*}{$\begin{array}{c}\text { 85878A } \\
\text { Gneiss } \\
5 \mathrm{~m}\end{array}$} & \multirow{2}{*}{$\begin{array}{c}85878 \mathrm{~B} \\
\text { Gneiss } 5 \mathrm{~m} \\
\text { pegmatoid } \\
\text { part }\end{array}$} & \multirow{2}{*}{$\begin{array}{c}85882 \\
\text { Gneiss } \\
20 \mathrm{~m}\end{array}$} & \multirow{2}{*}{$\begin{array}{r}85886 \\
\text { Amph. } \\
2.5 \mathrm{~m}\end{array}$} & \multirow{2}{*}{$\begin{array}{l}85885 \\
\text { Amph. } \\
\text { contact }\end{array}$} & \multirow{2}{*}{\multicolumn{2}{|c|}{$\begin{array}{l}85884 B \quad 85884 A \\
\text { Biotitized Pegm. } \\
\text { amph. contact } \\
\text { contact }\end{array}$}} & \multirow{2}{*}{$\begin{array}{c}85883 \\
\text { Pegm. } \\
3 \mathrm{~m}\end{array}$} \\
\hline & & $30 \mathrm{~cm}$ & & & & & & & & & & & & \\
\hline & & 52.36 & 57.12 & 72.64 & \multicolumn{2}{|c|}{64.71} & \multicolumn{2}{|c|}{71.87} & 70.80 & 52.51 & 52.09 & & 75.38 & 74.32 \\
\hline TiO, & 0.05 & 0.08 & 0.14 & 0.13 & \multicolumn{2}{|r|}{0.16} & \multicolumn{2}{|r|}{0.21} & 0.22 & 1.41 & 1.16 & & 0.07 & 0.07 \\
\hline $\mathrm{Al}_{3} \mathrm{O}_{8}$ & 27.47 & 26.61 & 23.02 & 15.52 & \multicolumn{2}{|c|}{19.63} & \multicolumn{2}{|c|}{13.63} & 14.26 & 15.35 & 14.59 & & 15.10 & 14.54 \\
\hline $\mathrm{Fe}_{2} \mathrm{O}_{8}$ & 1.41 & 1.68 & 2.13 & 1.43 & \multicolumn{2}{|r|}{1.84} & \multicolumn{2}{|r|}{1.56} & 1.73 & 11.33 & 11.17 & & 0.74 & 0.72 \\
\hline $\mathrm{MnO}$ & 0.02 & 0.05 & 0.06 & 0.03 & \multicolumn{2}{|r|}{0.01} & \multicolumn{2}{|r|}{0.03} & 0.03 & 0.23 & 0.23 & & 0.01 & 0.06 \\
\hline $\mathrm{MgO}$ & 0.87 & 1.11 & 1.30 & 0.57 & \multicolumn{2}{|r|}{0.88} & \multicolumn{2}{|r|}{0.41} & 0.46 & 4.63 & 5.28 & & 0.26 & 0.22 \\
\hline $\mathrm{CaO}$ & 14.33 & 13.05 & 9.50 & 4.43 & \multicolumn{2}{|r|}{6.66} & & 1.22 & 1.35 & 10.96 & 10.74 & & 3.52 & 1.48 \\
\hline $\mathrm{Na}_{2} \mathrm{O}$ & 1.49 & 3.59 & 3.34 & 3.55 & & 4.13 & & 4.06 & 4.90 & 1.73 & 2.33 & & 4.11 & 2.80 \\
\hline $\mathrm{K}, \mathrm{O}$ & 0.72 & 0.40 & 1.29 & 0.74 & & 0.86 & & 6.54 & 5.88 & 0.41 & 0.74 & & 0.50 & 5.33 \\
\hline $\mathbf{P}_{2} \mathrm{O}_{5}$ & 0.01 & 0.01 & 0.07 & 0.01 & & 0.01 & & 0.04 & 0.05 & 0.13 & 0.11 & & 0.01 & 0.01 \\
\hline $\mathrm{H}_{2} \mathrm{O}$ & 1.16 & 1.04 & 1.99 & 0.92 & & 1.08 & & 0.35 & 0.27 & 1.30 & 1.54 & & 0.26 & 0.41 \\
\hline Rb ppm & 46 & 24 & 107 & 57 & 66 & 56 & & 266 & 235 & 14 & 27 & & 18 & 165 \\
\hline $\mathbf{S r}$ & 104 & 117 & 173 & 145 & 173 & 73 & & 157 & 189 & 109 & 122 & & 185 & 183 \\
\hline $\mathbf{Z r}$ & 0.6 & + & 26 & 70 & & 34 & & 156 & 213 & 89 & 76 & & 33 & 56 \\
\hline $\mathbf{K} / \mathbf{R} \mathbf{b}$ & 130 & 137 & 100 & 107 & 108 & 98 & & 204 & 208 & 243 & 226 & & 233 & 268 \\
\hline quartz vol. \% & 3.9 & 5.3 & 3.9 & 39.8 & 16.7 & 22.8 & 23.1 & 26.2 & 24.6 & 3.6 & 7.5 & 13.1 & 49.7 & 36.7 \\
\hline plagioclase & 78.2 & 78.7 & 63.2 & 52.1 & 72.7 & 65.2 & 25.4 & 29.5 & 32.4 & 37.3 & 31.5 & 34.4 & 48.2 & 28.2 \\
\hline K-feldspar & - & $\rightarrow$ & - & + & - & 0.9 & 49.5 & 36.8 & 39.5 & - & - & 0.1 & + & 27.3 \\
\hline hornblende & - & 2.2 & - & - & - & - & - & - & - & 51.7 & 54.1 & 0.2 & - & - \\
\hline pyroxene & - & - & - & - & - & - & - & - & - & 5.8 & 0.3 & - & - & - \\
\hline biotite & 0.7 & - & 2.3 & 0.1 & 2.1 & 5.4 & 0.8 & 7.1 & 2.6 & - & - & 49.6 & 1.3 & 3.0 \\
\hline chlorite & 2.0 & 2.6 & 6.4 & 4.3 & 5.2 & 0.8 & - & - & - & - & 0.1 & - & - & - \\
\hline epidote & 11.4 & 9.5 & 19.2 & 3.1 & 3.1 & 3.9 & + & 0.4 & 0.1 & 0.3 & 5.2 & 1.8 & - & - \\
\hline muscovite & 3.7 & 1.2 & 5.0 & 0.6 & - & 0.9 & - & - & 0.4 & - & - & - & 0.8 & 4.8 \\
\hline zircon & - & - & - & - & - & - & + & + & + & - & - & + & - & - \\
\hline others & + & 0.4 & - & - & 0.1 & + & $1.1^{*}$ & + & 0.3 & 1.3 & 1.3 & 0.8 & - & - \\
\hline$\%$ An & 90 & $75-61$ & 56 & 45 & 42 & $39-42$ & 29 & 31 & 29 & 55 & 44 & 40 & $31-40$ & 31 \\
\hline
\end{tabular}

* mainly garnet

Locality IA Boundary anorthostte-gnetss

85868 typical anorthosite, $10 \mathrm{~m}$ from the gneiss contact 85873 anorthosite, $30 \mathrm{~cm}$ from the gneiss contact

$\mathbf{8 5 8 7 2}$ thin pegmatite, forming the border between anorthosite and gneiss

Contact anor thosite-gnelss

85871 D anorthosite in contact with gneiss 85871 B gneiss in contact with anorthosite 85871 A gneiss approx. $15 \mathrm{~cm}$ from the anorthosite contact
Gnelss with pegmatold schlleren $5 \mathrm{~m}$ from the anorthostte contact

85878 A normal gneiss

85878 B pegmatoid schlieren

85882 typical gneiss, $20 \mathrm{~m}$ from the anorthosite contact

Locallty IB Boundary amphibolite-pegmatite

85886 amphibolite $250 \mathrm{~cm}$ from the nearest pegmatite

85885 amphibolite in contact with pegmatite

85884 pegmatite in contact with amphibolite

85883 centre of the same pegmatite sheet, $3 \mathrm{~m}$ from the amphibolite contact 
Table 7 (cont.). Analyses of contacts of acid rocks with anorthosite and amphibolite

\begin{tabular}{|c|c|c|c|c|c|c|c|c|c|c|c|}
\hline \multirow{2}{*}{$\begin{array}{l}\text { Loc. } 1 C \\
85893 \\
\text { Amph. } \\
40 \mathrm{~cm}\end{array}$} & \multicolumn{3}{|c|}{ Amphlbollte-blottte-rich schlleren } & \multicolumn{4}{|c|}{ Loc. 2 Amphibolite tncluston } & \multicolumn{4}{|c|}{ Loc. 3 Leucogabbro-gnelss } \\
\hline & $\begin{array}{c}85894 \\
\text { Hbl- } \\
\text { Bl-rock }\end{array}$ & $\begin{array}{c}85895 \text { A } \\
\text { Bi-rich } \\
\text { schlieren }\end{array}$ & $\begin{array}{c}85895 \text { B } \\
\text { Gneiss }\end{array}$ & $\begin{array}{c}89395 \mathrm{~A} \\
\text { Amph. } \\
20 \mathrm{~cm}\end{array}$ & $\begin{array}{c}89395 \text { B } \\
\text { Amph. } \\
\text { contact }\end{array}$ & $\begin{array}{r}89395 \text { C } \\
\text { Gneiss } \\
\text { contact }\end{array}$ & $\begin{array}{c}89396 \\
\text { Gneiss } \\
50 \mathrm{~cm}\end{array}$ & $\begin{array}{c}94201 \\
\text { Leuco- } \\
\text { gabbro } \\
2 \mathrm{~m}\end{array}$ & $\begin{array}{c}94202 \mathrm{~A} \\
\text { Leuco- } \\
\text { gabbro } \\
\text { contact }\end{array}$ & $\begin{array}{l}94202 \text { B } \\
\text { Gneiss L } \\
\text { contact }\end{array}$ & $\begin{array}{l}94202 \mathrm{C} \\
\text { Leucogabbro } \\
1 \mathrm{~cm} \text { incl. } \\
\text { in gneiss }\end{array}$ \\
\hline 46.99 & & \multicolumn{2}{|c|}{66.40} & 49.02 & 48.75 & 63.59 & 59.75 & 47.76 & 57.54 & 61.41 & \\
\hline 0.99 & & \multicolumn{2}{|c|}{0.75} & 1.08 & 1.03 & 0.76 & 0.96 & 0.13 & 0.24 & 0.57 & \\
\hline 13.11 & & \multicolumn{2}{|c|}{13.18} & 13.97 & 13.97 & 13.98 & 15.62 & 23.00 & 20.83 & 19.00 & \\
\hline 14.58 & & \multicolumn{2}{|c|}{6.77} & 13.67 & 14.01 & 7.44 & 7.81 & 4.46 & 3.46 & 3.19 & \\
\hline 0.24 & & \multicolumn{2}{|c|}{0.10} & 0.21 & 0.25 & 0.11 & 0.12 & 0.12 & 0.08 & 0.06 & \\
\hline 8.40 & & \multicolumn{2}{|c|}{4.33} & 8.00 & 7.32 & 3.43 & 4.08 & 5.86 & 3.00 & 3.10 & \\
\hline 9.75 & & \multicolumn{2}{|c|}{2.12} & 11.03 & 9.98 & 5.02 & 5.04 & 13.24 & 9.14 & 7.08 & \\
\hline 2.23 & & \multicolumn{2}{|c|}{2.27} & 1.25 & 2.66 & 3.33 & 3.59 & 1.47 & 3.30 & 3.11 & \\
\hline 1.62 & & \multicolumn{2}{|c|}{3.22} & 1.03 & 1.30 & 1.72 & 2.26 & 1.49 & 1.05 & 0.59 & \\
\hline 0.05 & & \multicolumn{2}{|c|}{0.05} & 0.09 & 0.11 & 0.08 & 0.23 & 0.01 & 0.16 & 0.22 & \\
\hline 2.01 & & \multicolumn{2}{|c|}{0.76} & 0.64 & 0.59 & 0.48 & 0.46 & 2.46 & 1.16 & 1.61 & \\
\hline 118 & & \multicolumn{2}{|c|}{317} & 16 & 41 & 82 & 116 & 98 & 66 & 35 & \\
\hline 87 & & \multicolumn{2}{|c|}{112} & 129 & 189 & 256 & 276 & 125 & 226 & 228 & \\
\hline 30 & & \multicolumn{2}{|c|}{89} & 51 & 56 & 150 & 374 & + & 90 & 295 & \\
\hline 114 & & \multicolumn{2}{|c|}{84} & 531 & 263 & 174 & 162 & 126 & 132 & 140 & \\
\hline 0.5 & 0.3 & 29.3 & 42.2 & - & 2.0 & 22.0 & 36.0 & - & 7.7 & 22.2 & 10.5 \\
\hline 22.9 & 0.2 & 50.8 & 51.1 & 29.2 & 24.7 & 36.2 & 44.1 & 38.8 & 64.2 & 64.4 & 69.1 \\
\hline - & - & 0.5 & 3.1 & - & - & 0.9 & + & - & - & 1.4 & - \\
\hline 50.7 & 45.6 & - & - & 65.5 & 60.6 & 19.7 & 3.7 & 26.4 & 16.1 & 4.1 & 6.3 \\
\hline - & - & - & - & - & - & - & - & - & - & - & - \\
\hline 5.9 & 53.4 & 18.7 & 2.8 & 2.2 & 11.7 & 20.2 & 15.7 & - & - & - & 8.3 \\
\hline 3.9 & - & - & - & - & - & - & - & 3.2 & 0.5 & 3.9 & 1.3 \\
\hline - & - & 0.6 & 0.6 & 3.0 & 0.6 & 0.1 & - & 21.8 & 9.8 & 3.6 & 4.0 \\
\hline - & - & - & 0.2 & - & - & - & - & 9.8 & 1.6 & 0.3 & 0.4 \\
\hline - & + & + & - & + & + & + & + & - & - & + & - \\
\hline $16.1 \dagger$ & 0.4 & 0.1 & + & + & 0.4 & 0.8 & 0.4 & - & + & + & + \\
\hline 36 & & 34 & 30 & 32 & 31 & 31 & 31 & 88 & 53 & 49 & 49 \\
\hline
\end{tabular}

t mainly calcite

Locallty IC Amphlbollte passing into blotite-rich schlleren 85893 amphibolite, $40 \mathrm{~cm}$ away from gneiss. This amphibolite passes along strike within a few metres into

85894 hornblende-biotite rock

Gneiss with biotte-rich schlieren which appears to be derived from amphibolitic material

85895 A biotite-rich schtieren

85895 B gneiss in contact with A

Locality 2 Amphtbollte inclusion surrounded by hornblendeblotte gnetss

89395 A centre of the inclusion, $20 \mathrm{~cm}$ away from gneiss
89395 B amphibolite in contact with gneiss $89395 \mathrm{C}$ gneiss in contact with amphibolite

89396 hornblende-biotite gneiss, $50 \mathrm{~cm}$ away from the nearest amphibolite inclusion

Locality 3 Leocogabbro-gneiss

94201 meta-leucogabbro, $2 \mathrm{~m}$ away from neosome material

Contact between leucogabbro and microgranttlc grtelss

94202 A leucogabbro in contact with microgranite 94202 B microgranite in contact with leucogabbro $94202 \mathrm{C} 1 \mathrm{~cm}$ leucogabbro inclusion in the gneiss 
is lowered in localitites 1 and 2 . The amphibolites at locality $1 \mathrm{~B}$ show the same increase in quartz content.

(3) Although the gneisses and pegmatites at locality 1 contain appreciable potash feldspar at some distance from the anorthositic rocks and amphibolites, no potash feldspar occurs in the contact samples. Also the contact samples in localities 2 and 3 contain hardly any potash feldspar. Near the contact with gneisses or pegmatites, the hornblende or pyroxene in the anorthosites and amphibolites are biotitized or, if no hornblende or pyroxene is present, the plagioclase breaks down to epidote and muscovite.

(4) The $\mathrm{Si}, \mathrm{Na}$ and $\mathrm{K}$ contents of the anorthositic rocks increase towards the contacts with the gneisses in locality 1 and decrease in the gneisses toward the contact with the anorthosites. The opposite effect is found for A1 and Ca. For the leucogabbroic rocks of locality 3 the same changes are found. For the amphibolites the effects are less clear, except for the behaviour of $K$ at locality $1 B$. These chemical effects agree with the mineralogical changes described above.

(5) $\mathrm{Rb}, \mathrm{Sr}$ and $\mathrm{Zr}$ are low in the anorthositic rocks of locality 1 and increase towards the boundary with the gneisses; in the latter the amounts of $\mathbf{R b}$ and $\mathbf{Z r}$ decrease towards the anorthosites. Especially for $\mathrm{Zr}$ the effect is marked. For the amphibolites and leucogabbros the effects are less clear, but $\mathrm{Zr}$ is clearly enriched in the contact sample of leucogabbro.

(6) The $\mathrm{K} / \mathrm{Rb}$ ratio in anorthosites and amphibolites is always very low. In locality 2 it decreases towards the gneiss.

(7) The width of the zones in which these chemical and mineralogical changes take place cannot be precisely assessed with the material studied, but is probably in the order of a few decimetres.

(8) The changes in the amphibolites transformed into biotite-rich schlieren in gneiss (locality 1C) agree with the effects described above for the contact zones between amphibolite and gneiss.

\section{Discussion}

Although the data are limited to at few occurrences, the modal and chemical analyses clearly show that the anorthosites and amphibolites underwent changes near the contact with gneisses. These changes can be summarized as an enrichment in $\mathrm{Si}, \mathrm{Na}$ and $\mathrm{K}$, i. e. those elements which are assumed to be particularly mobile and active in migmatic metasomatic processes (Mehnert, 1968, p. 147), together with a depletion, or dilution, of other elements. Increase in quartz content, change of the plagioclase towards a more sodic composition and the transformation of 
hornblende into biotite + epidote and calcic plagioclase into muscovite + epidote + more sodic plagioclase are the mineralogical expression of these chemical changes. The mobility of some trace elements is also evident, notably of $\mathbf{R b}$, and even of $\mathrm{Zr}$ which generally is regarded as a relatively immobile element. Moreover, the bigger mobility and enrichment of $\mathbf{R b}$ in respect to $\mathrm{K}$ in hydrous solutions causes the lowering of the $K / R b$ ratio, which otherwise should be high, in the metasomatized basic rocks. These results support the opinion that amphibolites and anorthosites locally can change towards a gneiss composition through reaction with hydrous mobilizates rich mainly in $\mathrm{Si}, \mathrm{Na}$ and $\mathrm{K}$. This does not necessarily mean that normal gneisses may be formed by metasomatism of amphibolites and anorthosites, but it is the writer's personal opinion that this may be the case, especially when the gneisses contain schlieren or boudins of amphibolite or anorthositic rocks, when they contain abundant epidote, when the plagioclase is more calcic than normal or when relics of the mafic minerals characteristic of the basic rocks are present. The fact that the boundaries between the gneisses and amphibolites or anorthositic rocks commonly are sharp does not conflict with this hypothesis, since Korzhinskii (1970) has demonstrated that gradual transitions between metasomatically reacting rocks are not normally to be expected.

\section{References}

Emmons, R. C. 1959: The Universal Stage. Mem. geol. Soc. Amer. 18.

Franzini, M. \& Leoni, L. in press: A full matrix correction in X-ray fluorescence analysis.

Memorie Soc. tosc. Sci. nat. A.

Korzhinskii, D. S. 1970: Theory of metasomatic zoning. Oxford: Clarendon Press.

Mehnert, K. R. 1968: Migmatites and the origin of granitic rocks. Amsterdam Elsevier Publ. Co. Windley, B. F. 1969: Anorthosites of southern West Greenland. Mem. Amer. Ass. Petrol. Geol. 12, 899-915. 